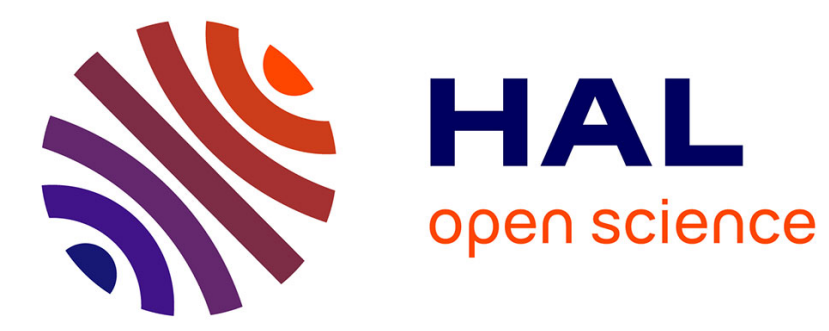

\title{
Varieties of Legal Intermediaries: When Non-Legal Professionals Act as Legal Intermediaries Jérôme Pélisse
}

\section{To cite this version:}

Jérôme Pélisse. Varieties of Legal Intermediaries: When Non-Legal Professionals Act as Legal Intermediaries. Studies in Law, Politics, and Society , 2019, 81, pp.101 - 128 . 10.1108/S1059433720190000081005 . hal-02959998

\section{HAL Id: hal-02959998 \\ https://hal-sciencespo.archives-ouvertes.fr/hal-02959998}

Submitted on 10 Feb 2022

HAL is a multi-disciplinary open access archive for the deposit and dissemination of scientific research documents, whether they are published or not. The documents may come from teaching and research institutions in France or abroad, or from public or private research centers.
L'archive ouverte pluridisciplinaire $\mathbf{H A L}$, est destinée au dépôt et à la diffusion de documents scientifiques de niveau recherche, publiés ou non, émanant des établissements d'enseignement et de recherche français ou étrangers, des laboratoires publics ou privés. 


\title{
Varieties of Legal Intermediaries. When Non-Legal Professionals Act As Legal Intermediaries
}

\author{
Jérôme Pélisse \\ Professor of sociology \\ Center for Sociology of Organization (CNRS), Sciences Po Paris \\ 19 rue amélie 75007 Paris (France) \\ jerome.pelisse@sciencespo.fr
}

Accepted for publication bu Study in Law, Policy and Society vol 81, pp. 101-128, 2019

\section{$\underline{10.1108 / S 1059-433720190000081005}$}

\begin{abstract}
:
Legal intermediation is an emerging theoretical concept developed to grasp the importance of the process and actors who contribute to legal endogenization, in particular in the field of economic activities and work governed by various public regulations. This article proposes to extend the analytical category of legal intermediary to all actors who, even if they are not legal professionals, deal on a daily basis with legal categories and provisions. In order to deepen our understanding of these actors and their contribution to how organizations frame legality, this paper investigates four examples of legal intermediaries who are not legal professionals. Based on four field surveys conducted over the past fifteen years in France on employment policy, industrial relations, occupational health and safety regulation, and forensic economics, I make three contributions. First, the cases show the diversity of legal intermediaries and their growing and increasingly reflexive roles in our complex economies. Second, while they are not legal professionals per se, to different degrees, these legal intermediaries assume roles similar to those of legal professionals such as legislators, judges, lawyers, inspectors, cops, and even clerks. Finally, depending on their level of legitimacy and power, I show how legal intermediaries take part in the process of legal endogenization and frame ordinary legality.
\end{abstract}

Keywords: legal intermediaries; legal endogeneity; legal consciousness; professions; France; labor; economy 


\section{I- Introduction}

Legal intermediation is an emergent theoretical notion developed to grasp the complexity of the process of legal endogenization and the diversity of actors who contribute to it, especially in the area of economic and labor activities that are targeted by diverse public regulations. This article proposes to extend the analytical category of legal intermediaries, not only to contexts like France, but to all the actors who, even if they are not legal professionals, deal on a daily basis with legal categories and provisions in their professional activities.

In order to deepen our understanding of these actors and of how they contribute to framing legality, this article compares different types of non-legal professionals who act as legal intermediaries. It is based on a broad overview of the literature on intermediaries and four field studies conducted by the author over the last decade on employment policy, industrial relations, occupational health and safety regulation, and forensic economics. Comparing the activities and roles of non-legal professionals in different contexts enables us to determine the main dimensions and variations of legal intermediaries and to develop a theoretical framework on this specific dimension of the legal intermediation process. While other contributions in the present special issue address other dimensions of the process of legal intermediation - such as the tools and instruments involved, like contracts, their temporality or their structural conditions - this article focuses on a specific set of actors who play a crucial role in this process.

This analytical account of the work performed by legal intermediaries is substantiated with results I collected on four sites of field research. The empirical cases include job counselors in French unemployment policy; Human resources managers and union's activists in companies in France; safety officers in French and American scientific laboratories developing nanoparticles; and forensic economic experts testifying before French courts. Drawing on the sociology of professions and neo-institutionalist, organizational, and socio-legal perspectives, this paper compares legal intermediaries with very different characteristics. This comparison 
seeks to understand how the legal environment frames economic and labor practices through the activities of professionals who act as legal intermediaries. It questions how rules are produced and implemented, supported and embodied by specific actors. These actors are not passive towards the law. They translate law-in-the-books into law-in-action, shape ordinary legality and what we take for granted as being "what the law says." By doing this, their action has a transformative effect on the law. Rights mobilization (McCann, 1994), legal consciousness studies (Ewick and Silbey, 1998) and legal endogeneity theory (Edelman, 2016) are the three main theoretical inspirations that I build on to craft the analytical category of "legal intermediaries." The article therefore returns to this notion, its origins and purposes, its definition and the issues that this category allows to address. By opening the notion of legal intermediaries to all the actors at the interface between the legal field and other fields (notably, but not only, organizational fields), who use law in their daily activities but are not legal professionals, their figures are empirically extended to many actors working in public institutions and agencies, companies and public interest associations or many other organizations. This empirical expansion yields convincing results, particularly in the four cases mentioned above. We show for example how crucial are the legal environments in which they navigate, the audiences with whom they interact, their ability and training to be reflexive when they handle legal rules. More or less close or far from the heart of the legal field, legal intermediaries play in moving and porous spaces. I therefore propose to compare them by using the power dimensions in which they find themselves, and which they mobilize when they broker between the legal field and other fields.

In the remainder of this article, the second part presents the theoretical issues and aims of a research agenda centered on legal intermediaries. The third part presents the different legal intermediaries that are analyzed in this article. This section lists the methods I used to collect and process data on legal intermediaries. It focuses then on the main power-oriented dimensions 
used to compare legal intermediaries. The fourth part proposes two main results. The first is related to the growing and increasingly reflexive roles of legal intermediaries in our complex economies. The second finding opens a paradox: these non-legal professionals who act as legal intermediaries assume often simultaneously roles similar to those of legal professionals, such as legislators, judges, lawyers, inspectors, police officers and clerks. Finally, I discuss the conditions in which legal intermediaries influence and shape legality. I show that depending among their level of power and legitimacy, legal intermediaries contribute to how organizations frame legality and take part in the process of legal endogenization in multiple ways. The conclusion proposes a very brief synthesis and opens future research perspectives.

\section{II- Theoretical framework: the analytical category of legal intermediaries}

Legal intermediary is a relatively novel category, which only a few scholars have used so far (see Talesh and Pélisse, 2018; Edelman, 2016; Talesh, 2015a,b; Stryker, 2011; Edelman, 1992 in the United States; Pélisse, 2014; Bessy, 2014; Bessy, Delpeuch et Pélisse, 2011; Spire and Weidenfeld, 2011 in France; and also Guillaume, 2015 in Great-Britain or Gendreau, 2005 in Canada). Despite its novelty, this notion has a broad theoretical basis which builds on three main approaches. I will discuss them and then propose my own conceptual definition of legal intermediaries.

\section{Between street level bureaucrats and legal professionals, the centrality of neo- institutionalist approaches}

A first origin of the idea to consider some actors as legal intermediaries is the research on street level bureaucrats and their administrative discretion. This line of research was initiated by Lipsky (1980) in the early 1980s and has subsequently expanded both in Great-Britain and in the United States (Maynard-Moody and Musheno, 2004; Watkins-Hayes, 2009; Maynard- 
Moody and Portillo, 2010; Hupe, Hill and Buffat, 2015 for examples). I claim indeed that legal intermediation is a key dimension of the work performed by street level bureaucrats. Thanks to their inherent autonomy when deciding how rules apply in practical situations, they are "ultimate policy-makers" (Portillo and Rudes 2014, 322-23). Street level bureaucrats contribute to the implementation of public policies by translating legal rules into provisions, administrative procedures, and many other documents. They represent the missing link between the State and the citizen, the administration and the public, or between policy-makers and policy-users. In France, this line of argument has been imported and reinterpreted by scholars who are interested in the interactions between low-level civil servants and their audiences underprivileged people, foreigners, the unemployed, senior citizens, etc. This literature, known in French as "Sociologie du guichet" (sociology of the counter), typically insists on the way these interactions are structured by social determinants such as class, gender, or organizational characteristics (Dubois, 2010). In these various empirical contributions, the reliance of street level bureaucrats on rules is central to understand the various ways in which laws are implemented and interpreted. Front-line workers and street-level bureaucrats - and even more so the mid-level bureaucrats (Cavalcante et Lotta, 2015) or "back office" bureaucratic managers (Spire, 2008) who have more leeway to interpret and apply the rules - are thus considered as brokers between the formal and legal rules and the people who are targeted by those policies and regulations. A recent article even analyzed judges in family courts in both France and North America as street-level bureaucrats (Biland and Steimetz, 2017, who recalls that Lipsky himself had referred to judges as possible street-level bureaucrats). The job counselor helping the unemployed to find a new job, one of the actors considered in my own fieldwork, - is a typical street level bureaucrat. However, the notion of legal intermediaries goes beyond the classical questions addressed in the literature on street level bureaucrats: rather than focusing on their discretion and on how they affect policy through implementation, the legal intermediation 
perspective draws attention to how they use and handle the legal rules, which helps understanding whether and how they influence the legality and legal consciousness of their audience.

In a broader perspective, intermediaries have nurture empirical and theoretical works in many sub-fields of sociology such as sports and culture, political sociology, economic sociology, social studies of finance, labor market studies, or science and technology studies. Cultural intermediaries who stand between the market and the public like producers, theater owners, food reviewers, or founders of new magazines have been the object of well-known studies (Hennion, 1989: Karpik, 2000; 2010; Haveman and alii, 2012). Intermediaries like agents in professional sports are now analyzed at the intersection of the sociology of markets, professions and sports (Demazière and Jouvenet, 2013). In economic sociology, there is a sprawling literature on traders, brokers and other entrepreneurs, who use their intermediate positions to further entrepreneurial projects (Zalio, 2013). Human resources specialists and hiring departments (Marchal, 2015) became central figures in the analysis of professions and labor market trends. Finally, in social studies of science (Meyer, 2010) as well as in the sociology of controversies or power in public policy (for example Lascoumes et Lorrain, 2007), brokers also became a central topic for many empirical researches.

This trend exists not only in France, but also in other academic spaces. In a publication in an American journal, Stovel and Shaw (2012) have called for a development of sociological research on brokers and brokerage. The neo-institutional perspective has also furthered the understanding of brokerage. Ever since Di Maggio published his landmark article on this topic (1988), this neo-institutional literature has indeed discussed the role of institutional entrepreneurs, emphasizing their ability to broker between their various networks and to position themselves as intermediaries between different worlds (Lawrence and Suddaby, 2006; 
Battalina, Leca, Boxenbaum, 2009; Bergeron et Castel, 2016, for instance). Thus, like a missing link between structure and agency, intermediaries have proliferated in the literature, especially since the early 2000's.

Two mechanisms explain this diffusion of intermediaries into various fields of sociology and eventually into sociolegal scholarship: the first one is grounded on a paradigm shift in the social sciences during these years, and the second is based on the transformation of governance, regulation, and the role of the state. At a theoretical level, intermediation processes are indeed considered more and more important: the Actor Network Theory developed by Callon, Latour, or Akrich in France during the 1990s and its international success gave a central role to gobetweens, mediators and intermediaries (see notably Callon, 1986 for one of the first impulsion of this approach). From a very different perspective, social network analysis - from the founding works of Granovetter and Burt to the current sophisticated developments (Lazega, 2014) - has also focused much attention on these key actors who open up cliques and gain social capital and power by filling structural gaps. The French school of organizational theory has also developed since a long time an interest for what Crozier (1977) and Friedberg (1993) have defined as the "intersecting marginal," located between two or more systems of actions. And even Luhmann and Teubner and their systemic and autopoïetic theory based on autonomous spheres have showed interest for the actors and provisions (like "connected contracts" analyzed by Teubner, 2011), that couple and articulate spheres with each other, especially the economic and legal ones (see Delpeuch, 2011 who commented specifically this point by using the notion of legal intermediaries). Nevertheless, the notion of legal intermediaries remains confidential and recent, having curiously not spread as in other fields of social sciences.

A second reason for the rise of intermediaries in academic research is simply their growing role in the real world. Many arguments can be used to justify the empirical accuracy of the 
figure of the legal intermediary (Talesh and Pélisse, 2018) but I will only develop a few. Indeed, the location of lawmaking has shifted and the regulatory environment has gradually moved from a government to governance model. In the latter, state, business, and civil society actors act as "rule-intermediaries" that affect, control, or monitor relations between rule-makers and rule-takers (Abbott et al., 2017; Levi-Faur \& Starobin, 2014). They verify, test, audit or certify legal rules, a process that provides a key insight into legal intermediation. Nevertheless, this approach remains a top-down one. By contrast, our perspective is more bottom-up and interactive. The concept of legal intermediation highlights not only the process by which rule makers influence rule takers, but also encompasses the tools, instruments, and hybrid categories used by these intermediaries and their participation in law in action, sometimes law in the books and often ordinary legality, as defined by legal consciousness studies. ${ }^{1}$

\section{A theoretical strategy of research: borderline professionals, legal endogenity and legal}

\section{consciousness}

With this theoretical background in mind, I center my analysis on one specific type of legal intermediaries, namely non-legal professionals. Indeed, the few studies using this notion make no distinction between the legal intermediaries who are legal professionals and those who are not. In France, Spire (with Weidenfeld, 2009; with Alpes, 2014) evoked their role to understand the variation of what he calls "procedural capital" to understand the mobilization of administrative courts by citizens, assisted by NGOs or lawyers, who are all defined as "legal intermediaries." Lejeune and Orianne (2014) analyze "the construction of workers' rights consciousness through legal intermediation in Belgium." But those are defined as "legal

\footnotetext{
${ }^{1}$ As explained by Silbey (2005, p. 347), « the term legality refers to the meanings, sources of authority, and cultural practices that are commonly recognized as legal, regardless of who employs them or for what purposes. (...) The analytic construct "legality" names a structural component of society, that is, cultural schemas and resources that operate to define and pattern social life (Sewell 1992). Through repeated invocations of legal concepts and terminology, as well as through imaginative and unusual associations among schemas, legality is constituted through everyday actions and practices $»$.
} 
professionals active in a range of transactions as intermediaries, between citizens, governments agents, organizational members including employers and the law as a body of texts and set of processes and practices" (p. 225). There are, however, a few exceptions, such as Vincent's and Buchter's contributions to this special issue, which analyze respectively the roles of hospital directors and nurse managers, and of various activists working in companies and advocating different causes and related rights (disability, LGBT, muslims).

In the American literature non-legal professionals are mostly considered, especially in the work of Lauren Edelman. Most existing empirical works dedicated to legal intermediaries follow her approach, from her first contributions on Human Resources (Edelman, 1992; Edelman, Erlanger and Lande 1993; Edelman, Fuller, Mara-Drita, 2001) to her latest book on the legal endogenization of US anti-discrimination law (Edelman, 2016). Yet similar to Dobbin (2009) or Talesh $(2009,2015 a, b, 2017)$, Edelman is more interested in compliance professionals than, more broadly, legal intermediaries. Despite the expansion of actors potentially considered as legal intermediaries to non-legal professionals such as HR members, consultants, managers or insurers, most of these works lump all types of legal intermediaries together. They insist rather on their roles into compliance process, more than, in a more broadly perspective, on the way they articulate and manage conflicts between competing discourses of authority, including law, science, gender, economy, labor or health, depending of their professional field. The theory of legal intermediation is in this sense broader than the sole or main question of compliance, by exploring the articulation between the law and the various normative spheres. The questions are not only if and how legal intermediaries contribute to the managerialization of the law or the legalization of organizations, with more merely symbolic or substantive effects, as underlined by L. Edelman in her last book (Edelman, 2016). But more broadly, how do legal intermediaries articulate and manage conflicts between competing discourses of authority, like gender, labor and law (Albiston, 2010), medicine and law (Dodier, 
1993; Juston, 2016), science and law (Silbey, 2008; Stryker, 2011; Huising and Silbey, 2011; Pélisse, 2017), and obviously, organizations, management and its values - efficiency, productivity, etc. - and law (Pélisse, 2004a; Edelman, 2016).

Expanding legal endogeneity theory toward legal intermediation perspective, as evoked in the introduction of this special issue, explains why I am focusing on a particular type of legal intermediaries: non-legal professionals. I thus propose theoretical contributions in two fields: the sociology of legal professionals and its frontiers, and the study of legal consciousness in organizations, and the limitations they encounter. Let me explain how I propose contributions in these two areas, to ground a theory of legal intermediation, which is not restricted to the question of compliance.

First, expanding the category of legal intermediaries towards actors who are not legal professionals appears to be interesting and challenging to the sociology of legal professions. I focus thus on legal intermediaries who are not at the core of the legal field (Delpeuch, 2011) and don't share two important characteristics: to be trained as lawyers and /or to be member of an official legal institution. Obviously, the boundaries are porous, especially to distinguish between professional and lay people (an activist can become a legal professional), people trained in law or not (one can learn law as a self-taught person), or even actors who belong to a legal institution or not. One can be a member of a formal legal institution on an occasional basis, like jurors or temporary labor or business judges in France. Or one can work part-time for an institution with a different main occupation, like the French judicial experts who are physicians, architects or accountants, for examples, and are not allowed to become part of a legal profession. In one word, legal intermediaries are situated on a continuum between the core of legal field, dominated by legal professionals, and its most distant borders populated by nonlegal professionals. My empirical topic is thus about borderline cases with professionals who 
have little (or no) symbolic resources specific to the legal field, while participating in them, without officially being part of them. Moreover, I have two cases that are far from the core of the legal field, and two others closer, even if not formally into the legal field. Street bureaucrats contribute well to the implementation of laws and could be seen as working in a legal institution; but they generally have very few legal attributes and resources on which they can rely. The same applies to union activists and safety engineers, who work in private or public organizations, which are far from the legal field. Forensic economic experts, on the other hand, are closer to the heart of the legal field, since they are appointed by the judges and they work for them. But, as we will see, they cannot and should not rely on such legal resources to carry out their activities and they are not allowed to become legal professionals, by a full-time specialization in forensic economic expertise. The total or relative absence of legal and symbolic resources, as well as their distance from the core of the legal field, makes it fascinating to observe the work of legal intermediaries who are not legal professionals: we better highlight all the concrete operations of intermediation and construction of ordinary legality, at the border of the legal field and its interface with other fields. Finally, in relation to the works of Edelman, Stryker or Talesh, who also consider non-legal professionals, I broaden the category of legal intermediaries to include not only compliance activities and compliance actors, but more broadly, intermediaries who deal with legal rules without being legal professionals.

In addition, my approach is not only anchored into legal endogenity theory, but also into legal consciousness studies (Sarat, 1990; Merry, 1990; McCann, 1994; Ewick and Silbey, 1998; Pélisse, 2005, 2006). Indeed, tacking into account legal intermediaries who are not legal professionals is a means of overcoming certain criticisms made on this research perspective. Legal consciousness studies call to "go into small towns, rural and urban neighborhoods and observe how people in these places come to name, use or ignore the law as they build it in their own world" (Sarat and Kearns, 1995). By overthrowing the law-first perspective, which was 
dominant in law and society studies, legal consciousness studies emphasized the construction of legality in the everyday life and by ordinary actors, like in the famous book written by P. Ewick and S. Silbey (1998). This perspective has been very fruitful, inspiring major research since more than twenty years, both in France and in the United States. Legal consciousness studies also faced tough challenges, which were raised by various scholars (Garcia-Villegas, 2003; Pélisse, 2005; McCann, 2006). One challenge was acknowledge by Silbey herself (Silbey, 2005). Popular conceptions of law are indeed framed by organizations and professionals, that is to say actors, who are not totally "ordinary," and processes, which are not totally "horizontal". On the contrary, intermediate actors and mediation processes participate in the construction of ordinary legality. McCann and Haltom (2004) have for example showed how media and active campaigns could frame popular consciousness on tort law and tort litigation in the US. In the field of organizational studies, Hoffman (2003) has shown how organizational forms of taxi companies (cooperative or conventionally hierarchical) influence legal consciousness and dispute resolution between workers and supervisors in the firms. To use the term coined by D. M. Engel (2012) and discussed by M. McCann (McCann, 2012), the "vertical approach" to legal consciousness has to be maintained, and the baby should not have been thrown away with the bath water when the "horizontal approach" came about. The McCann's comment on the necessity to keep both vertical and horizontal approaches, however, points three critical issues, which open new perspectives. McCann indeed insists, as a political scientist working on social movements, on the "importance of studying ordinary rights activists" (McCann, 2012, p. 476-479). He calls also for "more sociology and power, please" (p. 479-484) and to be attentive to "the variable content of rights consciousness" (p. 484-486).

This program is exactly mine by focusing on legal intermediaries who are neither legal professionals nor only compliance specialists. Indeed, most of ordinary people are not confronted with legal professionals in everyday life, in the US as in France. Nor to rights 
activists or compliance professionals. On the contrary, ordinary citizens often interact with actors who professionally use legal rules, manage them in their professional, associative or militant activities, even if they are not legal professionals, compliance actors, or activists. Through their non-legal professional activities, these intermediaries frame legality and rights consciousness; they shape power relations, because they are in power relations with their clients, patients, publics and they influence their conception of legality and law. As McCann suggests, we have to study these actors more sociologically, by comparing them and systematizing the analyze, by taking into account of their characteristics and the contexts in which they work. Finally, by tackling various examples and comparing them with each other, this paper aims at illustrating variations in the construction of legality, rights consciousness, and power relations between social actors. In other words, studying legal intermediaries is a solution to articulate theoretically the horizontal and vertical approaches to legal consciousness. We could thus explore what role legal intermediaries play in framing ordinary legality and the construction of one hegemonic reality.

My perspective therefore goes beyond the question of compliance: it proposes to study the ways in which the law and other forms of normativity are articulated, through intermediate actors who are on the boundaries of the legal field, as well as compliance functions. By paying attention to the nature of the legal environment in which these actors operate, the types of legal rules they deal with in their daily professional lives, even if they are not legal professionals, and the relationships they develop with their audiences - clients, users, patients, including potential legal professionals with whom they may interact - I propose to explore the ways in which legal intermediaries frame legality. In other words, how they integrate themselves into power relations, how they are constrained but also rely on the law, how they depend but can 
also abstract themselves from the weight of the law and legal professionals to influence ordinary forms of legality.

\section{III- An empirical object: non-legal professionals acting as legal intermediaries}

By revisiting four fieldworks involving legal intermediaries the aim of this paper is to analyze what they have in common and to what extent they differ. The legal intermediaries I study are job counselors working in an experimental organization funded by the French State and related to a public agency for vocational training (Agency for the vocational training of adults, AFPA in French); union activists and HR members in various companies in France; safety officers in scientific labs in France and in the US; and forensic economic experts in France. I revisit these sites to specifically test the fruitfulness of the analytical category put forth in this article. Below I will explain the methods I used to carry out data collection, the different research contexts I encountered and the main empirical characteristic of the legal intermediaries I analyzed. I then present the main dimensions used to compare them, which are problematized by the question of power.

\section{Data, methods and empirical findings}

A first study focused on job counselors working in one of France's many experimental employment programs, here the Occupational Transition Contract (OTC) (Brun, Corteel, Pélisse, 2012). Employees who had been dismissed for economic reasons by firms of less than 1000 employees located in employment areas identified as "vulnerable", benefitted from a transition grant of up to one year that matched approximately their former net salary. They also had the right to work for short periods of time without losing their grant. As explained by one of its main designers, "The aim of the OTC is the return to sustainable employment, with the goal of updating and skills development, with personalized advice for people, particularly in 
terms of training". The law stated that each member was expected to "be active in their job search" and "to meet his counselor and regularly communicate to him the results of his actions". The empirical research consisted of interviews $(n=37)$ with job counselors and their managers, and numerous ethnographic observations $(n=70)$ at two sites, especially the interactions between job counselors and unemployed people, as well as internal meetings between job counselors. The experimental nature of the program has been interesting for us, researchers, because it has served as a magnifying lens to understand the daily interactions that shape the lives of the unemployed in France - and there are many of them in this country -, in particular with the job counselors in welfare job agencies. As legal intermediaries, job counselors frame the identity of the unemployed. They define what "looking for a job" or "building a career plan" means, what a "good" or a "bad" job is, as well as an "acceptable" or "unacceptable" job offer. In this sense, job counselors shape the meaning, the conventions and legality surrounding work which in turn impacts how the unemployed feel about their rights.

The second source of data is grounded in several inquiries on collective bargaining and conflicts at the company level. At first, I studied agreements over working time reduction that resulted from two laws passed in the late 1990s (Pélisse, 2004a, b). Then I collected data on the subsequent evolution of conflicts and negotiations (during two studies in 2006-2008, then 20122014) thanks to a survey covering more than 3000 French firms (Béroud et alii, 2008; Giraud et alii, 2014). During these years, I also conducted personally 15 in-depth studies of specific companies from various sectors (manufacturing, services, agriculture) and with different sizes (from 30 employees to 4000). I combined interviews with employers, employees and union members, document analysis and workplace visits. In France, unions are frequently present at the level of many firms (except for the smallest), which affects how companies endogenize labor law. Even though French industrial relations are not exclusively focused on the level of companies as in the United States, the trend since more than thirty years has been a 
decentralization of collective bargaining. As a result, HR managers and union's activists are more and more involved in the production of formal legal rules, contributing to the internalization of law by organizations. Their contribution is particularly salient in the negotiation of collective agreements, which concern not only wages, but all dimensions of the employment relationship (working time, working conditions, equal pay for men and women, dismissal conditions, etc.). This trend has also been strongly reinforced by the recent reforms of the Labor Code in 2016 and 2017, which considerably widened the autonomy of HR employees and union members in governing labor relations. These actors act thus as legal intermediaries between an evolving legal framework and practices on the workplace. They participate in the definition of the meaning of the laws especially during phases of negotiation and conflict, giving substance increasingly procedural legal rules. Of course, as Edelman's work points out, other legal professionals, such as lawyers, in-house counsel and judges (one could add labor inspectors) play important roles in this process. But they rarely intervene on the workplace, and when they do, it is under very specific circumstances. Representing employers on the one hand, and employees on the other, HR members and union activists are therefore key players in the legal process of endogenization. They frame ordinary legality in the workplace, producing, negotiating and implementing intrinsically technical and organizational, socio-economic and legal rules.

A third study is grounded in an ongoing research on health and safety in nanoscience labs, which I started in 2014. Five nano-medicine and nano-chemistry laboratories in three prestigious universities in France and the United States are being studied through numerous observations and a wealth of ethnographic data, with two colleagues. I interviewed academics $(\mathrm{PhD}$, postdoc and permanent scholars) and safety officers $(\mathrm{n}=70)$ to understand the construction of legality in scientific contexts. I notably pay attention to the role of safety officers who take part in this process, both inside and outside the labs. Among other things, they indeed 
enforce an increasing body of regulations, acting as legal intermediaries. Trained and recognized for their technical skills and competences related to safety, chemicals or health risks, safety officers complete documents, authorize or not experiments, monitor and ensure compliance in laboratories. They check the ability of laboratory workers to use any tool or equipment, and they check that they have their glasses, gloves, lab coat, etc. They play a crucial role between external regulations and internal practices in laboratories, developing a mediating role to ensure compliance of the labs and experimental practices. When they work in safety offices, as EHS officers, they turn legal rules, good practices or recommendations from the EU or agencies such as INRS, NIOSH, OSHA or EPA related to nano-risks into practical regulations. When they work in laboratories, as safety reps, they adapt these rules daily to the laboratory space, at the time of research (which can be Sunday or night), and to the passion and scientific spirit that characterize researchers (Pélisse, 2017). In every case, they act as legal intermediaries, even if they are far from the official legal field.

A last study was on the contrary closer to the core of the legal field. Indeed, I met French forensic economic experts, who are called by the judges to help them in complex business cases (Charrier and Pélisse, 2012). The data I collected here are both quantitative and qualitative: I surveyed 135 experts using an in-depth questionnaire and interviewed 17 together with Emmanuel Charrier, himself accountant and who became a forensic expert after the study. Appointed by judges, rather than by the litigants as in the US, forensic economic experts are professionals who are very close to the judicial field. They are nevertheless expected to focus only on the technical dimensions of the facts and refrain from counseling the judge on legal or judicial dimensions of the case. Moreover, they are barred from becoming fully-fledged legal professionals, as rules prohibit them from practicing as forensic experts on a full-time basis. Moreover, they rarely interact with the judge: most of their communication is based on the initial task sent by the judge through written documents. Even if they are not legal professional, 
they play an intermediary role between law in the books and law in action, between legal rules and economic actors, helping to define what is legal and what is not, and how to comply with it. They greatly influence judges' decisions, the perception of the law for litigants and certain aspects of the legality of cases. During meetings and interactions with litigants (and their counsels and lawyers), experts exert influence, interpret rules and construct the technical, social, and intrinsically legal meaning of the business rules.

\section{Three power dimensions for comparing legal intermediaries}

Beyond these successive identifications of legal intermediaries and their specific activities, the comparison between them yields variations. We can classify them along three dimensions that are closely related to power, in order to understand how and under what conditions legal intermediaries contribute to endogenizing the law and shaping ordinary legality.

The type of legal environment and legal rules handled and manipulated by legal intermediaries is the first important dimension to be considered when drawing a comparison. Indeed, legal environments are not simple or unique, and rules can be very different, between facilitating, regulatory and constitutive dimensions for example, to take the distinctions proposed by Edelman and Suchman (2007). One must distinguish between procedural and substantive rules, broad and ambiguous or precise and narrow rules, hard rules and other soft rules, in order to understand the context, the nature and the power that the legal intermediaries own and undergo ${ }^{2}$. These rules can be combined with various sanctions, ranging from exclusion from the program for employment counselors (for example, when job seekers do not come to the weekly meeting or do not seek employment) to refusal of an experiment by security officers. In one case in an American laboratory, they even excluded from the laboratory a $\mathrm{PhD}$ student

\footnotetext{
${ }^{2}$ See Billows (2016), who emphasizes this crucial dimension of the more or less ambiguity or formalized characteristics of the legal rules, to understand the various strategies of regulators, as the strategies of in-house counsels in retail sector.
} 
considered too dangerous, and forced him, with his director, to change his dissertation topic to avoid experiments. However, sanctions are rarely as harsh and mostly combined with other means, like humor or mockery, but also strikes (for unions' activists), dismissal (for HR employees) or calls to the judge (for forensic economic experts) to implement, enforce or merely use the rules.

A second dimension is the audiences with whom legal intermediaries interact, and the different types of power relationships that they entail. Unions' activists are elected by their audience. Others legal intermediaries receive their mandate from the State or a university, or, like $H R$, received a private mandate to represent the interests of the firms (and mainly the stakeholder and managers). These mandates could be permanent like for the job counselors or EHS officers, or temporary like for the judicial experts or the union's activists. In all cases, these dimensions must be specified in order to grasp the power relationship that exists between the legal intermediaries and their clients, users, audiences or supervisors. In this vein, to analyze the legal professionals with whom legal intermediaries interact, or who may be present in the practical and professional environment of legal intermediaries is important. For the French judicial experts in economics, it is not only the judge, for whom they work and write a report but, more and more, lawyers and "forensic counsels" appointed by the parties, with whom they must interact during the working meetings. For their part, unions' activists and HR members work more frequently with lawyers or in-house counsels, whereas job counselors can even be confronted with the judges, as in one of the studied centers. Even though a claim from jobseekers who sued the director of one of the two job center studied, was dismissed, the job counselors became very cautious about the procedural aspects of their activities, in order to avoid possible legal proceedings.

These two dimensions are related to the institutional legal intermediaries' power and authority, that we have to take into account to understand their capacity to shape legality. This 
institutional power is strong for job counselors, for example, who may exclude unemployed workers from the program, even if they have to justify their decision in front of their colleagues and the director of the job center. From one other side, HR and union members have a great deal of bargaining power to elaborate rules, although framed by the Labor Code, legislation and judges. Even if they are not in the front line to implement them directly, they can often be enforcement agents and help shape day-to-day workplace practices and ordinary legality. Because laboratory safety representatives share the daily lives of scientists (when they are not themselves scientists in training, such as safety representatives in American laboratories), they can intervene more directly in safety practices. But their power is weak because of their status (PhD students or technicians), their role (implementing external, bureaucratic and nonscientific rules in researchers' practices) and their lack of legitimacy compared to the authoritative discourse of science. Finally, for judicial experts in economics, because they own technical knowledge (inaccessible for judges), unrecognized but very important legal skills (notably to respect procedural rules) and a judicial horizon (essential for drafting their reports in a form satisfactory for judges), they have real power to influence both judges' decisions and the legality of business relationships.

I map thus these variations in the table below, in order to show empirical details, but also synthetic points of comparison between the four types of legal intermediaries analyzed.

(INSERT TABLE 1 HERE)

\section{IV- Results: a tendency and a paradox}

By contrasting these four different fieldworks and legal intermediaries along the main dimensions evoked above, I present two results. The first underlines the growing importance and reflexivity of legal intermediaries and the second highlights a paradox showing how the 
comparison is useful in understanding the roles of legal intermediaries, the conditions under which they develop their intermediary positions and activities and how they participate to the managerialization and legalization processes, shaping legality in workplaces or economic relationships.

\section{Tendency: the growing role of trained and reflexive legal intermediaries}

A first result is the growing, increasingly impactful and reflexive role of legal intermediaries in our complex societies and economies. In one word, it underlines their possible growing power in legal endogenization process. I suggest with Shauhin Talesh that three conditions have made intermediaries more likely to play a role in shaping legality: "the global shift from government to governance, the inherent ambiguity in legal rules, and the increasing complexity of legal rules" (Talesh and Pélisse, 2018, p. 5). We argue that the interaction of these three elements have created greater space for non-traditional actors to emerge and influence law. In particular, a variety of legal and non-legal actors among and within organizations that come into contact with law have increasing discretion in their legal environments. If the hypothesis of a growing juridification and legalization of organizations is true, then legal intermediaries (legal and non-legal professionals) have to play a growing role in our economies and societies, gaining leeway and power to contribute to the endogenization process.

The four cases presented above show this growing role of legal intermediaries and notably of non-legal professionals, in various areas. It is really visible to each of them, even if it is for various reasons. For job counselors, the policies - and the legal forms they take, as in the experimental program studied - give more space to local agencies and job counselors in the process of implementing social assistance. For industrial actors, laws are now regarded as supplementary and are only implemented if collective bargaining fails: the role of industrial actors in the drafting and implementation of labor laws in companies increases considerably. 
For safety officers, there is a very perceptible trend towards the legalization of scientific laboratories, which contrasts with the past situation marked only by the domination of scientific logic. And for experts in legal economics, even if they don't have more activities in recent years, their role has become central in increasingly complex business cases, at least when the latter are judged by the courts. Finally, the diversity of the cases evoked above nurture the idea that many professionals or occupational functions could be analyzed as possible example of legal intermediaries. We need to take a fresh look at many actors, including workers, civil servants, street and middle bureaucrats in private and public organizations, but also activists and many intermediaries function between the law and different worlds (science, sport, art, religion, etc.).

Secondly, although non-legal professionals, legal intermediaries are increasingly trained and called upon to be reflexive in their day-to-day management of legal rules. This is generally true, as in the fourth cases mentioned above. One has to notice, for example, how master's degrees especially dedicated to non-legal students and professionals at various American and French universities are multiplying since a few years. At Northeastern, since 2014, one master of legal studies "is a distinctive program built from the ground up for the aspiring professional eager to enhance his or her understanding of the law and to help employers navigate complex regulatory terrain. The Master of Legal Studies is for non-lawyer professionals who work regularly with lawyers and legal issues. It was created specifically for those who do not wish to practice law, but would like to use the law as a means to achieve goals in environments where law is too often seen as an obstacle" (http://www.northeastern.edu/mls/program). Mostly online and possibly at part-time, master of "science in law" at Northwestern and masters of "Legal studies" at Washington University, Pepperdine or University or Arizona - to take only a few examples - are designed in the same way and for the same audiences: non-legal professionals and non-lawyers. Most of the time developed by law schools - but sometimes by 
business schools or under the screen of ethics and compliance, notably in France too, these training courses are an evidence of the possible diffusion of these legal intermediaries roles and actors, and the need for them to be trained, if not reflexive.

This growing reflexivity and training in the use of rules - different from classical legal training - is visible to most of the legal intermediaries I study. Although the job counselors have not received legal training, they are all very familiar with the decree creating the OCT program. We were also struck by the importance of the collective discussions they had among themselves, to decide on a case, interpret the rules and establish local jurisprudence enabling them to share common and effective ways of accompanying the unemployed. For HR members and union activists, it should be noted that the former are increasingly trained, particularly in law but not exclusively. ${ }^{3}$ Union activists are increasingly specialized, as recent laws have transformed them into specialists of negotiation and "social dialogue." During my investigations, for example, many activists have incidentally explained how they had to become experts in labor law, learning and sleeping with the labor code to assume their mandate and their role. For safety officers in the world of science, the requirement for a high level of knowledge and expertise, as well as an ability to think about how to use it and implement the rules, is similar. At West University in the United States, for example, where I investigated in 2014 and 2016, I witnessed how the health and safety office has recruited more and more safety officers with PhDs in chemistry or biology. It is expected that these actors are able to understand the researchers and share their experiences to increase their effectiveness in implementing the safety regulations developed by the university. At another university, Huising and Silbey (2011) described and analyzed this reflexivity and "relational regulation" by which safety officers managed to implement a very complex environmental and health monitoring system. Finally,

\footnotetext{
${ }^{3}$ For example, $27 \%$ of the HR respondants to the surveys that I use in my inquiry (REPONSE) had a high diploma (between a bachelor and a master degree) or more in 1999. They are $41 \%$ in 2011 in the survey. This survey shows also the increasing time dedicated to legal counsels reported by unions'activists during these years.
} 
forensic economic experts must also be well versed in the rules of procedure and reflect on their relations with both litigants and judges. Since 2004, to have the right to be included on national lists of experts from which judges select their judicial experts, they have to prove every five years that they master procedural knowledge. In short, the first result is clearly the growing importance of these actors, not only in their diversity and number, but also in their training, reflexivity and possible power. They increasingly have to master develop strategic skills to make the most of the rules that surround them.

\section{Paradox: legal intermediaries and the legal professional roles}

A second result is a paradox concerning the role of the legal intermediaries analyzed in these studies. Indeed, even though they are not legal professionals, legal intermediaries act more or less as legal professionals. This does not mean that they mimic the legal professionals with whom they interact. But their treatment of legal rules put them in a similar position as legal actors. To a certain extent, they act indeed simultaneously as legislators, judges, lawyers, inspectors, cops and even as clerks. This is additional reason for seeing a continuum between their role and those taken up by legal professionals. As Nelson and Nielsen (2000) have pointed out, corporate lawyers in large law firms - which are also not at the heart of the legal field - act as cops, counsels or entrepreneurs. Similarly, we have found that our legal intermediaries frame legality following those different legal roles, despite being sometimes very far from the legal field. Edelman and Suchman (1999) also proposed the idea that organizations act as internal legislators, judges, lawyers and cops during the process of legal endogenization.

As legislators, legal intermediaries all contribute to the production of legal rules, which shape the practical legal environment for which, or with which, they work. As Talesh (2015) stated, "rule-intermediaries filter the meaning of the law through competing logics and, in so doing, act as legislators". They act as legislators by directly producing legal rules, such as HR staff and unions' activists in companies, through collective bargaining and collective 
agreements. For other legal intermediaries, it is more indirect. But, through their interpretation and reconstruction of the meaning of legal rules, the act of helping the unemployed, supervising compliance with safety rules in scientific laboratories, or helping the judge to understand and resolve business conflicts, they act as legislators. In some cases, these intermediary rules can be recognized by the legal order. Safety officers at universities produce memos and various documents, describe good practices and disseminate standards to other contexts. Judicial experts draft reports and propose solutions, which are often adopted by the judge, thus contributing to case law. Acting as a legislator does not even require the presence of a written rule. The job counselors, during their weekly meetings with the unemployed and with their colleagues at the job center, develop "secondary rules" (Lascoumes, 1990) and like a practical jurisprudence to implement the decree, which frames the experience of OCT's clients.

As judges, even if they mobilize other principles of justice, legal intermediaries develop judgment activities based on legal rules. This is particularly salient for job counselors, who constantly judge their public, the behavior of the unemployed or the quality of their project and their training, by referring to the rules of the OCT program but also to other principles (equity or equality; need to work; gender and its naturalization on the type of work for men and women; logic of the labor market; etc.). Forensic economic experts could also be particularly qualified as "judges of a small technical trial" (Charrier and Pélisse, 2012). They provide reports to the judge, but in reality, they do a lot more during their expertise: because they organize meetings, request documents and require the parties to plead their claims, the expertise process itself transforms the case. They often "clarify" the conflict and "drain" the case, acting as a judge, even if their contribution is limited to the technical dimension of the dispute. Safety officers also decide and judge in situation. They authorize or not an experiment, evaluate the risks in a room and decide whether to evacuate it or not. These decisions are based on technical knowledge, but also on legal categories such as liability, potential guilt or the precautionary 
principle. Union activists and HR managers, however, act less frequently as judges than others legal intermediaries. Yet the employer is a judge in his own company. He has the right to enforce internal rules, which can go as far as terminating someone's job contract. Incidentally, both HR members and union activists are sometimes judges in the local labor tribunals.

Third, as lawyers, legal intermediaries raise cases, defend interests and provide strategic advice. They mobilize, interpret, and manipulate the rules of law to defend their clients, who are their audiences, their employers, their voters. They can also choose to defend the "public interest." In the field of labor law, HR members are, in a way, lawyers for their employers and managers, while union's activists use the law to defend the interests of employees. Through the OCT program, job counselors defend the general interest and proper allocation of public funds. They are also the defenders of the unemployed, helping them to find a job, arguing their qualities before potential employers or training organizations and their funders. In a similar vein, safety officers are always mandated by the director of the laboratory or university and defend the cause of safety against other logics. For their part, judicial expert seeks the technical truth of the facts. These mandates require them to represent interests, defend cases and use legal rules to achieve strategic objectives. In this sense, legal rules are specific tools for them, as they are for lawyers. Legal intermediaries obviously have other resources and logic than legal rules, such as their technical knowledge, their experiences, their legitimacy to represent employees. They infuse other professional logics than the legal logic to do their job, contributing to filter the law through their professional knowledge and practices.

Fourth, as cops, legal intermediaries monitor compliance of practices with legal rules. They inspect systems, procedures and practices. The specific legal intermediaries on whom I have focused don't only advise on and interpret the meaning of the law, defining what is to be compliant or not with the law. They all enforce the rules and monitor compliance. This is clearly the case for job counselors and safety officers (the latter being often called cops by the 
scientists), as well as economic forensic experts who check whether litigants give them access to information, figures and documents, and are often considered as the judge's sword arm by the litigants. Legal intermediaries channel behaviors and seek compliance, like union activists who want the labor code to apply in their companies and often play the role of enforcers. HR members act less like cops than the others. Nevertheless, they rarely share totally the point of view of the managers and supervisors, carrying on the gaps between practices and legal rules of the Labor code, and underlining often the importance to respect the rules ${ }^{4}$.

Finally, as clerks, legal intermediaries increasingly report on how they implement and use the rules. They become registrars of law and legality, formalizing the situations they have to manage, implementing legal rules through formal procedures and sometimes through software and written reports, which allow them to control their audience. I observe this process among different legal intermediaries, such as job counselors or safety officers - some of them are even called "paper engineers" by safety reps in French and American scientific labs. Faced with an increasing proceduralization of their activity, under the effect of the growing presence of corporate lawyers and "forensic accountants", judicial experts in economics have also described how they record and account for all their activities, in particular by paying attention to the calendar and deadlines. As for HR members and union activists, they increasingly have to account, write and report how they negotiate, what they said when they meet, etc. Like the clerk during the trial, legal intermediaries record what the rules say, how they are implemented, what their effects are, because they must be responsible and trace responsibilities, as the law itself promises. From a Weberian perspective, legal intermediaries are perhaps one of the most invisible but effective agents of the diffusion of the legalistic state (Epp, 2009) and of formalization, if not rationalization of our daily life.

\footnotetext{
${ }^{4}$ Charles Epp (2009) emphasizes for example the role of these actors, who contribue to the legalization and bureaucratization of various administrations or companies, by overstating the judicial risks of illegal or not compliant behaviors.
} 


\section{V- Discussions and conclusion: framing legality through institutional, contentious and uncertain dimensions}

With these results, we can open a discussion of how legal intermediaries shape ordinary legality and eventually contribute to legal endogeneity. The line of questioning moves away from what they do in practice (as legislators, judges, lawyers, etc. as shown above) and must now assess the consequences of those practices on our legal consciousness. We can now analyze whether and how legal intermediaries managerialize the law or legalize organizations, and whether they contribute to more substantial or symbolic effects in the process of legal endogenization, to frame the question like L. Edelman does her latest book (Edelman, 2016). For example, trade union activists are primarily motivated by the legalization of organizations: as Selznick (1969) pointed out, they attempt to transform industrial relations systems to fight arbitrariness, establish general rules to protect employees, and advance workers' social rights. On the contrary, HR members are more likely to contribute to the management of law and regulation, to use legal rights to promote their managerial interests and to construct the meaning of law in a way that is compatible with their managerial values of efficiency, rationality, and productivity. But the issue is not just about compliance and how they interpret, implement, legalize or managerialize laws; it is about understanding how they shape legality through their everyday work (which involves legal rules and other forms of normativity) and their interactions with various audiences. We must therefore take into account the power dimensions described above and analyze how they contribute to an institutional process rather than a political process, if we use again the analytical notions proposed by Edelman and her coauthors. With this distinction, Edelman and Stryker (2005) emphasize that:

\footnotetext{
"Two processes are at work in linking law and the economy: institutional process that involve the production and widespread acceptance of particular construction of law and compliance, and political
} 
process that help to shape which constructions of law are produced and became institutionalized and who benefit from this construction" (Edelman and Stryker, 2005, p. 933).

"Neo-institutional theories of organizations can be modified to emphasize both institutional conditions under which taken for grantedeness is likely to prevail and in which these conditions could be fragile, such latent conflicts of meaning, values and interests evolve into manifest conflict” (ibid, p. 938).

How do legal intermediaries influence the construction of what is taken for granted and considered as an institutional reality, or, on the contrary, how do they contribute in more controversial ways to legal endogeneity and legality?

One hypothesis could be formulated here: when intermediaries play an important role in framing legality (they have the power, legitimacy, capacity to control and construct the meaning of legal rules), they further strengthen the institutional process described above. When they perform various legal roles with legitimacy, they participate in "the production and widespread acceptance of a particular construction of law and conformity," to quote Edelman and Stryker (2005). By contrast, when legal intermediaries are weaker, less legitimate and less connected, when they are more constrained by rules than the strategic actors who use them, the process of legal intermediation is less institutionalized, more political and contentious. Considering my four cases could be a test for this hypothesis and a step forward in understanding how different legal intermediaries act during the legal intermediation process and with what kind of consequences on day-to-day legality.

On the side of job counselors, their power and legitimacy vis-à-vis unemployed jobseekers are clearly high, particularly for the majority of the unemployed who are in a situation of relative dependency (lack of financial resources, low qualification, age, etc.) ${ }^{5}$. Thus, job counselors try to change behaviors: jobseekers should market themselves on the labor

\footnotetext{
${ }^{5}$ That is not the case of all the unemployed, even if they are dismissal for economic reasons: some of them search alone a job and feel them not dependent of the job counselors or the OCT program. Even if this is very rare, others refuse the device of OCT, because they refuse to meet their job counselors every week and, precisely to be dependent of the OCT program and their job counselor.
} 
market, improve their skills and adapt their vision of employment. One main contribution of the job counselors is to transform labor conventions, by shifting the expectations of jobseekers from the notion of "lifelong employment" to that of "sustainable employability" (Brun et alii, 2012). By doing this, they transform certain aspects of legality. They redefine popular conceptions of what "looking for a job" and "a good job" stand for, what skills are useful in the labor market. They convince jobseekers that nowadays it is necessary to change one's job regularly, through flexible contracts and permanent adaptations. In other words, employment counselors clearly contribute to an institutionalized process of legal intermediation. Obviously their public is temporary rather than captive: unemployed people find a job, or stop looking for one (especially for health reasons) and the program I studied gives them consistent support only for one year. This time period is sometimes not enough to transform the situations and identities of the unemployed. But the job counselors have the means during this year to influence their situations and, because the experimentation lasted 7 years in all, they contributed, among others, to alter the collective beliefs regarding job search, "reasonable" jobs and the role of vocational training in finding a new job. In a nutshell, they influenced those constitutive categories in an institutional way, which are less officially legal than shaping informally legality.

Turning to union activists and HR members, I found that they are mainly concerned with the regulatory environment: the legal rules that matter to them are mainly statutes that regulate work organizations and workplace practices. These rules determine wages, working time, training time, job classifications, health and safety and working conditions, etc. Moreover, HR members and union activists are often conflicting with each other. They defend competing interests yet they have to cooperate to make organizational life possible. Because negotiations and conflicts are ultimately always about rules - procedural or substantive -, both HR and union members influence constitutive norms. In doing so, they contribute both to the institutional and political forms of legal intermediation. Their interactions are highly institutionalized and even 
ritualized, especially when the union's activities and legitimacy are recognized by employers, mostly in large companies. But this institutional framework, largely regulated by the Labor Code, creates interactions that are structurally contentious. In these interactions, the parties contest each other's legitimacy, especially when they act as legal intermediaries. Thus, when they act as judges, inspectors or cops in companies, the other parties often contest their conclusions. And when they invent rules through collective bargaining, it is always through agreements that are often seen as a temporary armistice in the "cold strike" that bind and oppose them (Morel, 1980). Finally, they also shape legal consciousness in the workplace, influencing day-to-day legality and the constitutive categories of what is a job and a company, what is work, wages or "normal" working time. But this influence is often controversial, especially in France where the conflict dimension of labor relations is often and always topical.

For safety officers at university, the legal environment is also made of regulations: those rules allow certain types of experiments and prohibit others, regulate the use of chemicals and establish a precautionary principle. Nevertheless, these legal intermediaries are clearly dominated in laboratories by the expertise of researchers and the scientific logic. This is particularly the case for internal safety representatives who lack power, can rarely sanction and call upon outside authorities. Paradoxically, they seek to be forgotten by scientists: they are more successful in implementing safety practices in laboratories when they do not have to remind scientists of the rules and can disappear behind their other roles (scientists themselves in American laboratories, or technicians helping with experiments in French laboratories) (Pélisse, 2017). Outside safety officers are closer to mid-level bureaucrats: they have a clearer and deeper understanding of the rules. Their status as university bureaucrats and inspectors (even when they inspect labs only once a year) gives them authority. They translate the legal regulations into the organization of the university and the scientific labs, interacting with legal professionals like OSHA,EPA inspectors or in-house lawyers at university. Beyond these 
differences, they share nevertheless the same position vis-à-vis scientists and the same role in the legal intermediation process. They seek to institutionalize this process, through what they call "a living safety culture," but are often seen by scientists as "too political": scientists often blame them for referring to external rules that they consider too bureaucratic, formal and irrelevant.

Finally, judicial experts in economics are immersed in a judicial environment shaped by very precise procedural rules, but also by very contentious relations. They are called by judges to assist them in particularly contentious and complex situations. They do not act directly or formally as judges, but they organize their activities like them, meeting with the parties, requesting documents, listening to their arguments and ruling what the decision on the technical dimension of the trial might be. They thus try to "empty" and "drain" the conflict of its technical aspects, by observing where the parties have complied or not, by judging how they defend their interests and by seeking a technical truth. And when they succeed - for example, when the parties accept their authority and find their relationships and reports fair - it is because they convince and shape the perceptions of those parties. As we have shown (Charrier and Pélisse, 2012), judicial experts in economics shape the social and moral conventions of a fair business relationship, for judges but also for litigants. They thus contribute to the institutionalization of certain interpretations of the interaction between business and law (and justice), even when the context and initial situation are highly controversial.

Legal intermediaries are therefore immersed in various legal environments and have unequal leverage over these environments and in their interaction with their audiences or legal professionals. As summarized by figure 2, they contribute mostly in some cases to the institutionalization of legal intermediation, and rather to politicizing in other cases.

(Insert figure 2 here) 
The role of legal intermediaries in legal endogenization processes is complex, depending on the legal environment and the rules they deal with on a daily basis, their relations with their audiences and legal professionals, their authority, power and legitimacy in the situations at hand. However, the variability is not fortuitous, and, in each case, legal intermediaries have a major impact on legality, whether it is the unemployed, workers and managers, scientists in their laboratories or litigators in commercial cases. I argue that it is essential to consider their role in how organizations endogenize legal rules and build legality that frames our daily lives and identities. Taking them into account aims at understanding how the legal and economic spheres interact and how this interaction varies according to specific issues, rules and contexts. This approach constitutes a promising avenue for systematizing the analysis of these interactions, the processes that take place there and their consequences on the ways the law is constructed and acts in our daily lives.

A final general remark on their intermediate position could be made: because they are brokers between the legal and organizational fields, between health and safety regulation and scientists, between the business logic and legal rules in litigation, or even between employees and employers, or unemployed and potential employers, these actors are both weak and strong, in-between and nowhere, in-between and everywhere. They are somewhere between the formalism of the legal field and its legal professionals and the informal phenomena pertaining to this field. Legal intermediaries can thus escape the logics of formalization and proceduralization, as well as they can legalize organizations and our daily lives. In this sense, their intermediate positions undoubtedly imply an intrinsic uncertainty. This uncertainty weakens their legitimacy to use the law and develop their various legal roles. But uncertainty is also a source of power, as M. Crozier and E. Friedberg (1977) have shown. Thanks to their intermediate position, legal intermediaries play with the rules, use different logics, cross 
borders, even more and in different ways than legal professionals. Legal professionals have indeed to abide to the logic of the legal field, which is very powerful, competitive and source of a strong "illusio," as explained by Bourdieu (1987). Legal professionals, much more than legal intermediaries, are partly dominated by their professionalism, the effects of competition and reputation and their professional rules, which imply a particular form of legal liability concerning them. The power developed by legal intermediaries thanks to their intermediate position is probably more informal than formal, more fragile, contested or politicized than institutionalized. But informality could be stronger than formality to participate in the process of legal endogenization, to shape our legal consciousness, to influence what is taken for granted and to frame ordinary legality in our social world.

\section{Aknowledgements:}

Thanks to Sebastian Billows, Lisa Buchter and John Cioffi for their help and comments on earlier drafts of this paper.

\section{References}

Abbott, K., Levi-Faur D. \& Snidal D., (2017). Theorizing Regulatory Intermediaries: The RIT Model. The Annals of the American Academy of Political and Social Science, 670 (1), 13-35.

Albiston C. (2010), Institutional Inequality and the Mobilization of the Family and Medical Leave Act: Rights on Leave, Cambridge, Cambridge University Press

Battilana J., Leca B., Boxenbaum E. (2009), How Actors Change Institutions: Towards a Theory of Institutional Entrepreneurship. The Academy of Management Annals 3(1), 65-107.

Bergeron H., Castel P. (2016). Les habits neufs du néo-institutionnalisme ? La redécouverte de l'ordre mésologique et de l'agency. L'Année sociologique 66(1), 31-72

Bessy, C. (2014), Économie des conventions et sociologie. Revue Française de SocioÉconomie, 13 (1), 259-265.

Bessy C., Delpeuch T., Pélisse J. (eds) (2011). Droit et régulations des activités économiques. Perspectives sociologiques et institutionnalistes, Paris, coll. Droit et société, LGDJ.

Biland E., Steimetz H. (2017). Are Judges Street-Level Bureaucrats? Evidence from French and Canadian Family Courts, Law and Social Inquiry, 42 (2), 298-324. 
Billows S. (2016). La politique de l'ambiguïté juridique. Quand l'Etat tente de réguler les échanges entre la grande distribution et ses fournisseurs. Sociologie du travail, 58, 8-31.

Bourdieu P. (1987). The Force of Law. Toward A Sociology of the Juridical Field. The Hasting Law Journal, 38, 805-853.

Brun F., Corteel D. \& Pelisse J. (2012). Counselling redundant employees in the framework of the occupationnal transitional contract programme : expertise and experience. Revue Française de Sociologie, 53 (3), 287-315.

Buchter L. (in this issue), Beyond Lip Service? Activists' Attempt to Influence Corporate Antidiscrimination Regulations in France.

Callon M. (1986). Eléments pour une sociologie de la traduction : La domestication des coquilles Saint-Jacques et des marins-pêcheurs dans la baie de Saint-Brieuc. L'Année sociologique, 36, 169-208

Cavalcante P. Lotta G. (2015), Middle-Level Bureaucrats : Profils, Trajectories, Performance, Brasilia, ENAP.

Charrier E., Pélisse J. (2012). Conventions at Work: On Forensic Accountant's Intermediation. Economic Sociology (European Electronic Newsletter), 14 (1). 31-40.

Crozier M. et Friedberg E. (1977). L'acteur et le système. Les contraintes de l'action collective, Paris, Points Seuil.

Delpeuch T. (2011). Les interfaces entre le juridique et l'économique : concept de couplage et intermédiaire du droit. In Bessy C., Delpeuch T., Pélisse J. (eds.). Droit et régulations des activités économiques. Perspectives sociologiques et institutionnalistes, Paris, LGDJ, 127-133.

Demazière D., Jouvenet M. (2013). The market work of football agents and the manifold valorizations of professional football players. Economic Sociology (European Electronic Newsletter, 15 (1), 29 - 40.

Di Maggio P. (1988). Interest and agency in institutional theory. In L. Zucker (ed.), Institutional patterns and culture, Cambridge, MA: Ballinger Publishing Company: 3-22.

Dobbin F. (2009), Inventing Equal Opportunity, Princeton University Press.

Dodier N. (1993). L'expertise médicale. Essai de sociologie sur l'exercice du jugement, Bruxelles, Métailié.

Dubois V. (2010). Politiques au guichet, politiques du guichet. In Borraz O., Guiraudon V. (eds), Politiques publiques 2. Des politiques pour changer la société ?, Paris, Presses de Sciences-po.

Edelman L. (1992). Legal Ambiguity and Symbolic Structures: Organizational Mediation of Civil Rights Law. American Journal of Sociology, 97, 1531-1576

Edelman L., Erlanger H., Lande D. (1993). Internal Dispute Resolution: The Transformation of Civil Rights in the Workplace, Law \& Society Review 27, 497.

Edelman L. and Suchman M. (1999). When the 'Haves' Hold Court: The Internalization of Disputing in Organizational Fields. Law \& Society Review, 33, 941-91.

Edelman, L., Fuller, S., Mara-Drita, I. (2001). Diversity Rhetoric and the Managerialization of Law. American Journal of Sociology, 106(6), 1589-1641. 
Edelman L., Stryker R. (2005). A sociological Approach to Law and the Economy In Smelser N.J. and Swedberg R., The handbook of Economic Sociology, Princeton University Press, 527551.

Edelman L., Suchman M. (2007). The Interplay of Law and Organizations. In Edelman L.B. and Suchman M. (eds.), The Legal Lives of Private Organizations, Ashgate Publishing.

Edelman, Lauren (2016). Working Law: Courts, Corporations, and Symbolic Civil Rights. Chicago and London: The University of Chicago Press.

Engel D. (2012). Vertical and Horizontal Perspectives on Rights Consciousness. Indiana Journal of Global Legal Studies, 19 (2), article 2.

Epp C. (2009). Making Rights Real: Activists, Bureaucrats and The Creation of the Legalistic State, Chicago, University of Chicago Press.

Ewick P., Silbey S. (1998). The Commonplace of Law. Stories of Everyday Life, Chicago, University of Chicago Press.

García Villegas M. (2003). Symbolic Power without Symbolic Violence? Critical Comments on Legal Consciousness Studies in USA. Droit et société, 53 (1), 137-163.

Gendreau C. (2005). 'Légitimation' et ‘délégitimation' du droit de l'État : le cas des pratiques professionnelles des intermédiaires du droit dans le contexte du divorce. In Coutu M. et Rocher G. (dir.), La légitimité de l'État et du droit. Autour de Max Weber, Laval, Presses de l’Université Laval.

Guillaume C. (2015). Understanding the variations of unions' litigation strategies to promote equal pay: reflection on the British case, Cambridge Journal of Economics, DOI 10.1093/cje/bev004, 17p.

Haveman H., Habinek J., Goodman L. (2012). How entrepreneurship evolves: the founders of new magazines in America, 1741-1860. Administrative Science Quarterly, 57 (4), 585-624.

Hennion A. (1989). An Intermediary Between Production and Consumption: The Producer of Popular Music. Science, Technology, \& Human Values, 14 (4), 400 - 424.

Hoffman E. (2003). Legal Consciousness and Dispute Resolution: Different Disputing Behavior at Two Similar Taxicab Companies, Law and Social Inquiry, 8 (3), 691-716.

Huising, R., Silbey S. (2011). Governing the gap: Forging safe science through relational regulation. Regulation and Governance (1), 14-42.

Hupe P., Hill M. and Buffat A. (2015). Understanding street-level bureaucracy, Chicago, University of Chicago Press.

Juston R. (2016). Le corps médico-légal. Les médecins légistes et leurs expertises, thèse de sociologie, , Université Versailles Saint Quentin en Yvelines.

Karpik L. (2010). Valuing the Unique. The Economics of Singularities, Princeton University Press.

Karpik L. (2000). Le Guide rouge Michelin. Sociologie du travail, 42 (3), 369-389.

Lascoumes P. (1990). Normes juridiques et mise en œuvre des politiques publiques. L'Année sociologique, 40 (3), 43-71.

Lascoumes P., Lorrain (2007). Trous noirs du pouvoir. Les intermédiaires de l'action publique. Sociologie du travail, 49 (1), 1-9. 
Lawrence T. and Suddaby R. (2006). Institutions and Institutional Work, in Clegg S., Hardy C., Lawrence T., Nord W. (eds), The Sage Handobook of Organization Studies, DOI $10.4135 / 9781848608030 . n 7$

Lazega E. (2014). Réseaux sociaux et structures relationnelles, Paris, Presses Universitaires de France.

Lejeune, A., Orianne, J.-F. (2014). The construction of workers' rights consciousness through legal intermediations: the case of employment discrimination in Belgium. International Journal of Discrimination and the Law, 14(4), 221-243.

Levi Faur D. Starobin J. (2014). Transational politics and policy: from two-way to three-way interactions. Jerusalem Papers in Regulation \& Governance, working paper 62.

Lipsky M. (1980). Street-level bureaucracy, Dilemmas of the Individual in Public Services, New York, Russell Sage Foundation.

Marchal E. (2015). Les embarras des recruteurs. Enquête sur le marché du travail, Paris, Editions de l'EHESS.

Maynard-Moody S., Musheno M. (2004). Cops, Teachers, Counselors: Stories from the Front Lines of Public Service, University of Michigan Press.

Maynard-Moody S., Portillo D.S. (2010). Street-Level Bureaucracy Theory In The Oxford Handbook of American Bureaucracy, Robert F. Durant Editions.

McCann M.W. (1994). Right at Work. Pay Equity Reform and The Politics of Legal Mobilization, Chicago, University of Chicago Press.

McCann M.W., Haltom W. (2004). Distorting the Law. Politics, Media and The Litigation Crisis, Chicago, University of Chicago Press.

McCann M.W. (2006). On legal rights consciousness: A challenging analytical tradition. In Fleury-Steiner B. and Nielsen L.B., The new civil rights research: a constitutive approach, Burlington, Ashgate Publishing.

McCann M. (2012). Expanding the Horizons of Horizontal Inquiry into Rights Consciousness: An Engagement with David Engel, Indiana Journal of Global Legal Studies 19 (2) article 4.

Merry S. (1990). Getting Justice and Getting Even. Legal Consciousness Among WorkingClass Americans. Chicago, University of Chicago Press.

Meyer, M. (2010). Les courtiers du savoir, nouveaux intermédiaires de la science. Knowledge brokers as the new science mediators. Hermès, La Revue, 57 (2), 165-171.

Nelson B., Nielsen L.B. (2000). Cops, Counsel, and Entrepreneurs: Constructing the Role of Inside Counsel in Large Corporations. Law and Society Review 34(2): 457.

Pélisse J. (2004a). A la recherche du temps gagné. Sens et usages du droit autour des $35 \mathrm{~h}$, these de sociologie, Université Marne la Vallée.

Pélisse J. (2004b). From Negotiation to Implementation. A Study of The Reduction of Working Time in France (1998-2000). Time and society 13 (2-3), 221-244.

Pélisse J. (2006), Time, Legal Consciousness and Power: The Case of France's 35-Hour Workweek Laws. In Fleury-Steiner B., Nielsen L.B. (eds.), New Civil Rights Research. A Constitutive Perspective, Ashgate / Darmouth Editions.

Pelisse J. (2005). A-t-on conscience du droit? Autour des Legal Consciousness Studies. Genèses 59. 
Pélisse J. (2014). Le travail du droit. Trois études sur la légalité ordinaire. Mémoire d'Habilitation à Diriger les Recherches, Paris, Sciences Po.

Pélisse J. (2017). Gérer les risques par le droit: articulation et intermédiation dans les laboratoires de nanosciences en France et aux Etats-Unis. Droit et société 96 (2), 321-336.

Portillo D.S., Rudes S. (2014). Construction of Justice at the Street Level, Annual Review of Law and Social Science, 10, 321-334.

Sarat A. (1990), "The Law Is All Over": Power, Resistance and the Legal Consciousness of the Welfare Poor. Yale Journal of Law \& the Humanities, 2 (2).

Sarat A., Kearns T. (1995). Law in Everyday Life. University of Michigan Press.

Selznick P. (1969). Law, Society and Industrial Justice, New York, New York University Press.

Silbey S. (2005). After Legal Consciousness. Annual Review of Law and Social Science, 1, 323-368.

Silbey S. (eds) (2008). Law and Science Vol I and II. Routledge.

Spire A. (2008). Accueillir ou reconduire. Enquête sur les guichets de l'immigration, Paris, Raisons d'agir.

Spire A., Weidenfeld K. (2011). Le tribunal administratif : une affaire d'initiés ? Les inégalités d'accès à la justice et la distribution du capital procédural. Droit et société 79(3), 689-713

Spire A., Alpes J. (2014). Dealing with Law in Migration Control: The Powers of Street-level Bureaucrats at French Consulates. Social \& Legal Studies, 23 (1).

Stovel K., Shaw L. (2012). Brokerage, Annual Review of Sociology. 38, 139-158.

Stryker R. (2011). L'intermédiation scientifique dans la mise en œuvre des lois antidiscrimination américaine. In Bessy C., Delpeuch T., Pélisse J., Droit et régulations des activités économiques. Perspectives sociologiques et institutionnelles, Paris, LGDJ, 183-202.

Stryker R., Docka D., Wald P. (2012). Employment Discrimination Law and Industrial Psychology: Social Science as Social Authority and the Co-Production of Law and Science. Law and Social Inquiry, 37(4), 777-814.

Talesh S. (2009). The Privatization of Public Legal Rights: How Manufacturers Construct the Meaning of Consummer Law. Law \& Society Rev. 43, 527-562.

Talesh S. (2015a). Rule-Intermediaries in action: how state and business stakeholders influence the meaning of consumer rights in regulatory governance arrangements. Law and Policy, 37(12), 1-32.

Talesh S. (2015b). Legal intermediaries: how insurance companies construct the meaning of compliance with antidiscrimination law. Law and Policy 37 (3), 209 - 239.

Talesh S. (2017). Data Breach, Privacy, and Cyber Liability Insurance: How Insurance Companies Act as "Compliance Managers" for Businesses. Law and Social Inquiry doi:10.1111/lsi.12303.

Talesh S., Pélisse J. (2018). How Legal Intermediaries Facilitate or Inhibit Social Change? LIEPP Working Paper $n^{\circ} 73$.

Teubner G. (2011). Networks as connected contracts. International Studies in the Theory of Private Law. 7, Hart Publishing 
Vincent F. (in this issue). Approaching legal intermediation through a micro-level "in action" perspective: the case of the 12-hour work derogation in French Public Hospitals.

Watkins-Hayes C. (2009). The New Welfare Bureaucrats. Entanglements of Race, Class and Policy Reform, Chicago, University of Chicago Press.

Zalio P.P. (2013). Sociologie économique des entrepreneurs. In Chauvin P.M., Steiner P., Zalio PP, Traité de sociologie économique, Paris, Presses Universitaires de France, 601-634. 
Table 1: Three power-oriented dimensions of legal intermediaries

\begin{tabular}{|c|c|c|c|c|}
\hline $\begin{array}{l}\text { Figures of } \\
\text { legal } \\
\text { intermediaries }\end{array}$ & Job counselors & $\begin{array}{l}\text { Union representatives } \\
\text { and Human Resource } \\
\text { members }\end{array}$ & $\begin{array}{l}\text { Health and safety } \\
\text { officers (in and } \\
\text { outside the labs) }\end{array}$ & $\begin{array}{l}\text { Judicial experts } \\
\text { in economy }\end{array}$ \\
\hline $\begin{array}{l}\text { Legal } \\
\text { environment }\end{array}$ & $\begin{array}{l}\text { Decree and legal } \\
\text { instructions from } \\
\text { the administration }\end{array}$ & $\begin{array}{l}\text { European rules, Labor } \\
\text { Code, judicial decisions } \\
\text { and legislations } \\
\text { Collective agreements on } \\
\text { various issues } \\
\text { Facilitative, regulative } \\
\quad \text { and constitutive }\end{array}$ & $\begin{array}{l}\text { European and national } \\
\text { rules and regulations; } \\
\text { international } \\
\text { recommendations, good } \\
\text { practices reports from } \\
\text { various agencies } \\
\text { (NIOSH, EPA...), etc. } \\
\qquad \begin{array}{l}\text { Facilitative and } \\
\quad \text { regulative }\end{array}\end{array}$ & $\begin{array}{l}\text { Procedural rules of } \\
\text { expertise (due } \\
\text { process, } \\
\text { contradictory } \\
\text { principle) and } \\
\text { substantive rules of } \\
\text { business } \\
\text { (commercial Code) } \\
\text { Mostly procedural } \\
\text { (facilitative) and } \\
\quad \text { constitutive }\end{array}$ \\
\hline $\begin{array}{l}\text { Related } \\
\text { audience } \\
\text { (including legal } \\
\text { professionals) }\end{array}$ & $\begin{array}{l}\text { Unemployed, but } \\
\text { also their } \\
\text { supervisors. } \\
\text { Sometimes } \\
\text { potential } \\
\text { employers and } \\
\text { funders for } \\
\text { training program. } \\
\text { Possibly judges (in } \\
\text { one case in my } \\
\text { fieldwork). }\end{array}$ & $\begin{array}{l}\text { For HR members: } \\
\text { directions, employees. } \\
\text { For union's activists: } \\
\text { employees, other union's } \\
\text { activists. } \\
\text { For both: Labor } \\
\text { inspectors and state } \\
\text { bureaucrats; lawyers; in- } \\
\text { house legal counsel and } \\
\text { legal activists; judges. }\end{array}$ & $\begin{array}{l}\text { Into the labs (safety } \\
\text { reps): scientists, with } \\
\text { various status and } \\
\text { power. } \\
\text { Outside the labs (EHS } \\
\text { officers): direction of } \\
\text { their office and the } \\
\text { university; PI and health } \\
\text { and safety reps } \\
\text { For both: Labor and } \\
\text { environmental inspectors } \\
\text { (like OSHA and EPA in } \\
\text { US); possibly judges }\end{array}$ & $\begin{array}{l}\text { Primarily litigants, } \\
\text { but also lawyers and } \\
\text { more and more } \\
\text { "forensic counsels" } \\
\text { called and paid by } \\
\text { the litigants. } \\
\text { The judges mission } \\
\text { the experts but they } \\
\text { rarely interact after } \\
\text { the assignment } \\
\text { letter. }\end{array}$ \\
\hline $\begin{array}{l}\text { Power and } \\
\text { authority of } \\
\text { legal } \\
\text { intermediaries }\end{array}$ & $\begin{array}{l}\text { Strong vis-à-vis } \\
\text { unemployed } \\
\text { jobseeker but they } \\
\text { have to justify } \\
\text { their power in } \\
\text { front of their } \\
\text { colleagues and } \\
\text { superiors in the job } \\
\text { center } \\
\text { Formally strong }\end{array}$ & $\begin{array}{l}\text { Power to negotiate and } \\
\text { produce legal rules } \\
\text { (notably to derogate to } \\
\text { Labor Code), but less } \\
\text { direct for the } \\
\text { implementation and rules } \\
\text { enforcement } \\
\text { Variable, depending of the } \\
\text { sectors and the firms }\end{array}$ & $\begin{array}{l}\text { Inside safety reps: lack } \\
\text { of power vis-à-vis the } \\
\text { scientists (they are } \mathrm{PhD} \\
\text { or technicians); } \\
\text { Outside EHS offciers: } \\
\text { real but only formal } \\
\text { power, considered as } \\
\text { bureaucrats by the } \\
\text { scientists } \\
\quad \text { Often weak }\end{array}$ & $\begin{array}{l}\text { Their reports and } \\
\text { opinions influence } \\
\text { greatly the judges } \\
\text { and their decisions. }\end{array}$ \\
\hline
\end{tabular}

Table 2: How do legal intermediaries participate to the legal endogenization processes and how do they shape ordinary legality?

\begin{tabular}{|l|l|l|c|c|}
\hline $\begin{array}{l}\text { Figures of legal } \\
\text { intermediaries }\end{array}$ & $\begin{array}{l}\text { Job } \\
\text { counselors }\end{array}$ & $\begin{array}{l}\text { Union representatives } \\
\text { and Human Resource } \\
\text { members }\end{array}$ & $\begin{array}{l}\text { Safety officers (in or } \\
\text { outside the labs) }\end{array}$ & $\begin{array}{l}\text { Judicial experts in } \\
\text { economy }\end{array}$ \\
\hline $\begin{array}{l}\text { More institutional or } \\
\text { political process of } \\
\text { legal } \\
\text { endogeneization? }\end{array}$ & Institutional & $\begin{array}{c}\text { Variable but mostly } \\
\text { political and contentious }\end{array}$ & $\begin{array}{c}\text { Will institutionalize but } \\
\text { perceived as actors } \\
\text { politicizing safety in the } \\
\text { labs }\end{array}$ & $\begin{array}{c}\text { Institutional but in } \\
\text { intrinsic contentious } \\
\text { context }\end{array}$ \\
\hline
\end{tabular}

